\author{
ARTUR HALASZ \\ University of Wrocław \\ artur.halasz@uwr.edu.pl \\ ORCID: 0000-0003-2279-4334
}

\title{
Statutory and operative definitions of legal terms in the tax law ${ }^{1}$
}

\section{Stanowione i operatywne definicje pojęć prawnych w prawie podatkowym}

\begin{abstract}
In this paper the author discusses the question of defining legal terms in the tax law. The author divides the definitions of legal terms contained in the tax law into statutory and operative definitions. This division is based on the distinction between statutory and operative law. Moreover, the author points to the operative definitions of legal terms in the tax law, which are of a quasistatutory nature.
\end{abstract}

Keywords: statutory definitions; operative definitions; tax law; defining legal terms.

Streszczenie. W opracowaniu autor porusza zagadnienie definiowania pojęć prawnych w prawie podatkowym. Autor podzielił definicje pojęć prawnych za-

1 The publication contains a number of theses and conclusions of the author contained in the monograph Definicje pojęć prawnych $w$ ustawodawstwie dotyczq̨cym podatków obrotowych, Wrocław 2019. 
wartych w prawie podatkowym na definicje stanowione i operatywne. Podział ten został oparty na podziale na prawo stanowione i operatywne. Ponadto autor wskazał na operatywne definicje pojęć prawnych w prawie podatkowym, które mają quasi-stanowiony charakter.

Słowa kluczowe: definicje stanowione; definicje operatywne; prawo podatkowe; definiowanie pojęć prawnych.

\section{General remarks}

Definitions of legal terms in tax acts, similarly as in the entire legal system, are used by the legislator to specify terms contained in normative acts. It is worth pointing out that definitions of legal terms in the tax law should be included in the acts, as it is the definition expressed in the normative act of statutory rank that will bind entities applying the tax law ${ }^{2}$. Definitions contained in other normative acts (of a rank lower than that of a statute) are binding only on the act and not on the statute. The exception to this is the case when a given definition is constructed in a normative act of a lower rank than the statute, but formulated on the basis of statutory authority. This definition is applicable to a certain extent in the Tax Act.

The definition of a legal concept contained in the Tax Act is binding on this Act and all its implementing acts - it is an internal scope of binding. Another issue is the external scope of binding of a given legal definition originating from other tax acts and acts outside the tax law system for the purposes of a specific tax act - however, this issue will not be analysed in this study.

Because of the principles applicable to tax law, the use of definitions of legal concepts by the legislator takes on a specific dimension. The basic issue is the principle of statutory tax regulation, as it defines the scope of exclusivity of a given tax act in the regulation of tax material ${ }^{3}$. The prima

2 B. Brzeziński, Uwagi o znaczeniu definicji w prawie podatkowym [in:] R. Mastalski (ed.), Księga jubileuszowa Profesora Marka Mazurkiewicza. Studia z dziedziny prawa finansowego, prawa konstytucyjnego i ochrony środowiska, Wrocław 2001, p. 226.

3 B. Brzeziński, Zasady ogólne prawa podatkowego (próba inwentaryzacji), „Kwartalnik Prawno-Finansowy” 2018, No 1, p. 31. 
facie principle should compel the legislator in the tax law to use the terms defined in a given tax act or in the system of law.

The following types of legal definitions can be distinguished in the system of law sensu largo: 1) real and nominal; 2) analytical and stipulative; 3 ) equivalent and non-equivalent ${ }^{4}$. These types exist in most branches of law. Because of the specific nature of tax law and its interferential nature, the definition of terms in tax law should be looked at in more detail.

There are two stages in the definition of legal terms in tax law: the stage of drafting tax law and the stage of its application. These stages determine the possibility of distinguishing between statutory and operative definitions of legal concepts, which will be subject to further analysis. The division into statutory and operative definitions of legal terms in the tax law refers to the concepts of statutory and operative law ${ }^{5}$.

The literature on the subject indicates that "operative law consists of decisions on the application of statutory law"6. However, "the basic form of lawmaking is legislative acts (normative acts)"”. In relation to this, it is pointed out that statutory and operative law are two separate ontological entities: one related to the development of law and the other to its application $^{8}$. However, in order for the operative law to exist, it is necessary to develop statutory law.

The doctrine of law indicates that "many terms used in legal texts do not have a precise scope and meaning"' . In the process of applying the law in such a case, "an organ applying the law always has two options either to consider the applied provision as «clear» and to use it directly, or to deem it questionable and subject it to interpretation"10. Therefore, where a concept is not defined in a tax law system, the entity applying the

4 "Generally, each of the distinguished types [of legal definitions] differs from the others in some respects” - A. Malinowski, Redagowanie tekstu prawnego. Wybrane wskazania logiczno-językowe, Warszawa 2006, p. 49.

J. Wróblewski, Rozumienie prawa i jego wykładnia, Wrocław 1990, pp. 14-16. Ibidem, p. 14.

7 W. Gromski, Stanowione prawo [in:] A. Bator (ed.), Wprowadzenie do nauk prawnych. Leksykon tematyczny, Warszawa 2010, p. 232.

J. Wróblewski, Rozumienie prawa..., p. 14.

J. Wróblewski, Sqdowe stosowanie prawa, Warszawa 1972, p. 118.

Ibidem. 
law must consider whether it needs to clarify the definition or not in accordance with the clara non sunt interpretanda principle. Should the entity determine that it is necessary to clarify certain terms not defined in the Tax Act, it creates an ad hoc definition of those terms for the purpose of a specific factual situation. As a result, an operative definition of a legal term in tax law is formulated. However, statutory definitions of legal terms are those created by the legislator and included in the normative act, i.e. the statute law.

\section{Statutory definitions of legal terms in tax law}

The definition of legal concepts in the legal system is related to the legislative technique, which "deals with the way legal texts are formulated"11, and with the lexical layer of the legal system, which for the legislative technique is one of the broadest and most important issues ${ }^{12}$.

The doctrine of tax law indicates that the nature of tax law forces the legislator to frequently use definitions contained in tax acts in the process of creating tax law ${ }^{13}$. The basic determinants of constructing definitions in a given tax act, in the process of creating tax law by the legislator, have been regulated in the regulation on "Principles of Legislative Technique» ${ }^{\text {. }}$. Pursuant to Article 146 PLT, definitions are formulated in the body of the Act when a given term is: ambiguous, vague; the meaning of a given term is not commonly understood; and there is a need to establish a new meaning of a given term ${ }^{15}$. Cases in which definitions of legal terms

\footnotetext{
J. Wróblewski, Zasady tworzenia prawa, Warszawa 1989, p. 134.

Ibidem, p. 136.

P. Borszowski, Wprowadzanie definicji legalnych w prawie podatkowym - zagadnienia wyjściowe, „Wrocławsko-Lwowskie Zeszyty Prawnicze” 2016, No 7, p. 221.

14 P. Borszowski, Wprowadzanie..., p. 224 et seq.; Ordinance of the Chairman of the Council of Ministers of 20 June 2002 (consolidated text: Dz.U. [Polish Journal of Laws] of 2016, poz. [item] 283), hereinafter: PLT.

15 More broadly see P. Borszowski, Definiowanie pojęć w prawie podatkowym jako ograniczenie obszaru nieostrości, „Wrocławsko-Lwowskie Zeszyty Prawnicze” 2017, No 8, p. 193.
} 
are formulated indicate that definitions are to contribute to the communicativeness of a given normative act.

The aspect of defining legal terms in order to increase the communicativeness of the text of the Tax Act should be considered in terms of the formulation and application of tax law. In the process of creating tax law, definitions expressed in the text of tax law are to ensure proper communication between the legislator and the addressee of tax law norm. In the process of tax law application, the burden is shifted from the legislatoraddressee relationship concerning tax law norm to the relationship between the addressee of tax law norm and the entity applying tax law - the entity deciding a particular tax case. Therefore, a common understanding of the legal concepts contained in the provisions of a given tax act by each of the parties to a tax relationship constitutes the foundation of that relationship ${ }^{16}$. Therefore, the process of applying the definitions of legal terms expressed in the content of the Act should be characterised by uniformity, and thus consistent application of these definitions.

Each tax has its own structure, which results from the text of a specific tax law ${ }^{17}$. When defining each element of the tax structure, the legislator uses specific terms which it defines either within the same tax law, or within another tax act, or a normative act of the rank of an act outside the tax law system, or it does not define this concept in the law system.

Defining legal concepts in the process of tax law creation, apart from implementing the principles underlying the process of tax law creation, is aimed at shaping particular elements of the structure of each of the taxes. The analysis of defining legal concepts of particular elements of various tax constructions leads to the conclusion that the legislator most often uses concepts defined outside the tax law system or undefined in the system of laws.

16 More broadly see A. Halasz, Stosowanie definicji stanowionych pojęć prawnych a zasada pewności w prawie podatkowym [in:] A. Kaźmierczyk, A. Franczak (ed.), Zasada pewności w prawie podatkowym, Warszawa 2018, p. 113 et seq.

17 A. Kostecki, Elementy konstrukcji instytucji podatku [in:] M. Weralski (ed.), System instytucji prawno-finansowych PRL, t. III, Warszawa 1985, p. 151. 
The application of statutory definitions of legal concepts by the legislator in tax law is characteristic for this branch of law ${ }^{18}$. However, in tax law, a given legal concept does not always have its own definition or a reference to a definition outside the given normative act. Therefore, in the process of determining the meaning of undefined legal concepts contained in a tax act, a major challenge for entities applying tax law is to implement the postulate of tax law certainty, i.e. its predictability and uniformity of application. This is because there are fundamental doubts in this process and the doctrine of law and judicature have not worked out uniform positions in this area. Therefore, this leaves ample space for creating operative definitions of terms in the process of tax law application.

\section{Operative definitions of legal terms in tax law}

Entities applying tax law define the undefined legal concepts from ad hoc tax laws. The creation of these definitions in the process of tax law application is what renders them operative definitions. The term "operative" indicates that these definitions are not regulated in the content of tax acts or in acts from other branches of law, despite the fact that they refer to concepts used by the legislator in tax acts - in the statute law. Therefore, an entity that creates operative definitions of legal terms is not the legislator, but the entity applying tax law - however, not each such entity.

The entities using operative definitions of legal terms in tax law are: courts, tax authorities, and taxpayers (payers, collectors, and third parties). However, because of the unequal nature of the tax law relationship of the parties, the analysis will focus on the development of such definitions by courts and tax authorities.

The important issue, however, is to answer the question: in relation to which terms do these entities formulate this kind of a definition? It should

18 P. Borszowski, Pomiędzy elastycznościq przepisów prawa podatkowego a definicjami legalnymi [in:] W. Miemiec (ed.), Księga jubileuszowa Profesor Krystyny Sawickiej. Gromadzenie i wydatkowanie środków publicznych. Zagadnienia finansowoprawne, Wrocław 2017, p. 475. 
be noted that these entities create operative definitions in relation to two types of concepts. First of all, concepts regulated in a given tax act, but lacking their definitions in the system of law. Secondly, concepts not defined in a given tax act, but defined sensu largo in other acts. Therefore, in the process of applying tax law, one can notice tendencies of entities applying tax law to establish their "own” definitions of such terms by referring to a common understanding of a given concept, or to a specialist understanding of a given concept, or to an understanding of a given concept in a legal language. As a result, at least three types of operative definitions of legal terms can be identified: 1) those referring to the common understanding of a given term; 2) those referring to the specialist understanding of a given term; 3) those referring to the understanding of a given term in the legal language.

The first type of operative definition of legal concepts is predominant in jurisprudence. This is confirmed by the judgment of the Supreme Administrative Court of 17 June $2016^{19}$ in which the court indicated that in the absence of a legal definition in a tax act, an operative definition of the term in common language should be applied. However, when a given concept is not defined in the tax act, but it is defined in the act concerning another branch of law, entities applying tax law handle this problem in various ways. In the literature on the subject, attention is drawn to the lack of a uniform model of using or developing such definitions in the case of a legal definition outside the tax law system ${ }^{20,21}$. In the doctrine of tax law

19 I FSK 54/15, LEX No 522210596.

20 In the judgment of the Supreme Administrative Court of 25 September 2015, II GSK 1176/14 (LEX No 522185532), the court pointed out that it was impossible to apply the definition of legal terms in everyday language in the absence of a definition of a legal term used in the Tax Act - similarly to the judgment of the Voivodeship Administrative Court in Rzeszów of 26 January 2017, I SA/Rz 740/16 (LEX No 522298436). However, "in many judgments it is repeated as a mantra that in the absence of a legal definition, the decision should be based on the common (ethnic, general, ordinary) use of a given term" (A. Bielska-Brodziak, Interpretacja tekstu prawnego na podstawie orzecznictwa podatkowego, Warszawa 2009, p. 33), and "in many $[\ldots]$ judgments, courts act towards [...] determining the meaning of the term to be interpreted on the basis of common language, without regard to the legal definitions contained therein” (A. Bielska-Brodziak, Interpretacja tekstu prawnego ..., p. 51). 
there exists a position according to which, in the absence of a given definition of a term in tax law, and its regulation e.g. in civil law, one should use a common understanding of the term, and the definitions provided outside the tax system may be of an auxiliary nature - however, this applies to situations where the definitions provided for legal terms outside the tax law system clearly differ in their content from the common understanding of the term ${ }^{22}$. When a defined term belongs exclusively to a legal language, e.g. a "real estate", but it functions in the common language, still as a concept derived from the legal language, the definition of such a term should be used in an act from another branch of law ${ }^{23}$. In such a situation, an entity applying tax law should not develop an operative definition of the term, but apply its statutory definition ${ }^{24}$.

The operative definition of legal terms in tax law based on the common understanding of a given term is not uniform. The literature on the subject indicates that administrative courts refer to three sources in order to determine the definition of a given term in a common language: “1) expert linguists’ opinions, 2) linguistic intuition, 3) linguistic dictionaries" ${ }^{25}$. Administrative courts in determining the definitions of terms not defined in the legal system, statistically most frequently use linguistic dictionaries ${ }^{26}$. However, it should be pointed out that these methods of obtaining a common definition of a given legal term are controversial.

21 "In this respect, it is appropriate to agree with the Court of First Instance that the interpretation of Article 43(1)(41) of the VAT Act using the definition of a storage contract under Article 835 of the Civil Code would lead to clarification of the concepts used in Directive 112 and taken over by the national VAT Act, using definitions contained in the internal law of the Member State. Such an interpretation of the concepts contained in the provisions of Directive 112 would undermine the effect that the regulations of the Directive should achieve" - judgment of the Supreme Administrative Court of 20 April 2016, I FSK 2027/14, LEX No 522157574.

B. Brzeziński, Wstęp do nauki prawa podatkowego, Toruń 2003, p. 206.

B. Brzeziński, Wykładnia prawa podatkowego, Toruń 2008, p. 294.

It should be emphasized that the formulation of operative definitions of legal terms in the case when the term has its definition in the act from outside the tax law system, is connected with the already signalled problem concerning the scope of legal definitions contained in the acts from outside the tax law system.

25 A. Bielska-Brodziak, Interpretacja tekstu prawnego ..., p. 25 et seq.

26 Ibidem, p. 270; Examples of judgments where administrative courts refer to linguistic dictionaries in defining of notions that are undefined in tax law: judgment of Supreme 
The first method, i.e. referring to expert linguists' opinions, is possible only if such evidence is taken during tax proceedings ${ }^{27}$. However, if such evidence is not used in tax proceedings, there is no legal basis for using it in administrative court proceedings. Therefore, this method is not used very frequently ${ }^{28}$. The second way, linguistic intuition, is burdened with too much freedom, which may result in a multitude of definitions of one concept that have been thus formulated. The third way, which consists of referring to language dictionaries, is heavily criticised in the doctrine of law on an account of the large number of published language dictionaries, which may differ as to the way in which a particular term is defined in everyday language. Such discrepancies may occur even across different editions of a linguistic dictionary ${ }^{29}$.

Similarly to administrative courts, tax authorities and taxpayers (payers, collectors, and third parties), in the absence of a legal definition of a given term, refer to a dictionary understanding of the term ${ }^{30}$.

Entities applying tax law define legal concepts with reference to a specialist understanding of a given concept - this is the second type of operative definitions. These definitions can be formed on the basis of a specialist literature (e.g. economic, technical or medical) ${ }^{31}$. This method is also exposed to the proliferation of definitions of a single term in a giv-

Administrative Court of 15 September1999 r., I SA/Gd 1139/97, LEX No 43945; judgment of Voivodeship Administrative Court of 31 January 2006 r., III SA/Wa 3162/05, LEX No 520316049; judgment of Voivodeship Administrative Court in Łódź of 9 January 2008 r., I SA/Łd 1022/07, LEX No 520556961.

Cf. Article 181 of the act of 29 August 1997 Tax Ordinance (consolidated text, Dz.U. of 2019, poz. 900).

28 A. Bielska-Brodziak, Interpretacja tekstu prawnego..., p. 26.

29 More broadly see ibidem, p. 28 et seq.; The same can be said of references to the understanding of the term in the legal language or specialised literature.

30 Examples of individual tax interpretations both in the part of a taxpayer's application (payer, collector, and third party) and in the part of an authority's interpretation where the entity applying tax law refers to the dictionary definition of a given concept include: individual tax interpretation by the director of the Tax Chamber in Katowice of 21 May 2010, No IBPI/2/423-353/10/MS, LEX No 184587453; individual interpretation by the director of the Tax Chamber in Warsaw of 28 November 2008, No IPPB5/423-56/08-2/AJ, LEX No 184636597.

31 Cf. K. Radzikowski, Glosa do wyroku WSA z dnia 4 września 2008 r., I SA/OI 165/08, „Finanse Komunalne” 2010, No 12, pp. 49-58. 
en literature, which is a natural result of a research conducted in various fields of science on particular issues ${ }^{32}$.

When operatively defining legal terms in tax law, entities also refer to a legal language - i.e. the third type of operative definitions. An example of the formulation of such a type of definitions is the judgment of the Supreme Administrative Court of 25 January 2012, in which the court rejected the dictionary definition of a term "representation" and used the understanding of the term in legal language ${ }^{33}$.

Thus shaped, operative definitions of legal concepts contained in the tax law system and not having their own legal definitions in tax acts, cause entities applying tax law either to create such definitions themselves, or invoke them in the course of tax or administrative court proceedings, thereby building a conviction about the quasi-precedented character of such definitions - and hence their absolute "validity".

Operational definitions of legal terms in the course of resolving tax cases are created ad hoc. They contain individual and specific rules. However, there may be exceptions to these principles. This inconsistency results primarily from the type of an entity that created a given operative definition and for what purpose.

The entities creating operative definitions of legal terms are primarily: tribunals (Constitutional Tribunal and Court of Justice of the European Union), administrative courts (voivodeship administrative courts and the Supreme Administrative Court) and tax authorities. The objective of creating a given operative definition varies. First of all, it may be related to the resolution of an individual case. Secondly, the objective may pertain not

32 In the judgment of the Supreme Administrative Court of 7 October 2010, II FSK 871/09 (LEX No 520839613), the court indicated that "it is not possible to refer to the definition of the term "lake" contained in specialist publications while reconstructing the norm resulting from Article 5(1)(1)(b) of the Act on local taxes and levies. It should be pointed out that these publications do not contain a single definition of the concept of a lake, consequently the application of specialist knowledge when defining this subject of taxation would introduce considerable uncertainty as to its understanding."

33 Judgment of the Supreme Administrative Court of 25 January 2012, II FSK 1445/10, (LEX No 521196476) - see also H. Filipczyk, Glosa do wyroku NSA z dnia 25 stycznia 2012 r., II FSK 1445/10, „Glosa. Prawo gospodarcze w orzeczeniach i komentarzach” 2012, No 4, pp. 113-119. 
to the resolution of an individual case, but to the explanation of discrepancies in interpretation - this is the case with the Supreme Administrative Court resolutions or general tax law interpretations issued by the Minister of Finance.

There is ambiguity in the development of operative definitions of legal terms by the Court of Justice of the European Union (in the case of judgments) ${ }^{34}$, the Supreme Administrative Court (in the case of abstract resolutions $\left.{ }^{35}\right)^{36}$ and the Minister of Finance (in the case of general tax law interpretations) ${ }^{37}$. In such instances operative definitions of legal terms take on a quasi-statutory character, as their scope of application is common. These definitions are also constructed by the Director of the National Fiscal Information and the Head of the National Fiscal Administration.

On account of the competence of these entities in specific legal institutions - the operative definitions of legal concepts constructed by them must be observed by other entities applying tax law. Therefore, these definitions are de facto quasi-statutory, although they have not been formulated by the legislator. Thus, in the case of an attempt to determine an understanding of legal concepts in tax law that do not possess their own definitions, it is important to analyse the Supreme Administrative Court resolutions, general interpretations and tax clarifications issued by the Minister of Finance and in specific cases: an interpretation of individual tax law provisions, advance tax rulings, and the established interpretative practice of the authorities of the National Treasury Administration. The operative definitions of legal terms constructed there may have binding force for other entities applying tax law ${ }^{38}$.

34 E.g. CJEU judgment of 4 May 2006, C-169/04, LEX No 520274302.

35 After S. Babiarz, Właściwość Naczelnego Sqqu Administracyjnego [in:] S. Babiarz (ed.), Postępowanie sq̨dowoadministracyjne w praktyce, Warszawa 2015, p. 35.

36 E.g. resolution of the Supreme Administrative Court of 27 February 2012, II FPS 4/11, LEX No 521204463.

37 E.g. general interpretation of the Minister of Finance No DD6/8213/11/KWW/07/MB7/82 of 5 March 2008, Official Journal MF 2008.3.27.

38 An example may be the fact of binding with operative definitions of legal terms by administrative courts if they are constructed in the Supreme Administrative Court resolutions - in accordance with Article 187(2) of the Law of Administrative Court Procedure the adjudicating panel is bound by the resolution of seven judges of the Supreme 


\section{Conclusions}

Despite the multitude of types and subdivisions of definitions of legal terms in the tax law system, it is important to devise a further division into the statutory and operative definitions of legal terms. The interfering nature of tax law requires attention to be paid to defining terms in tax law, both during the process of creation, and during the application of the said law. Therefore, we distinguish two fundamental types of definitions: statutory and operative.

Utilising statutory and operative definitions of legal concepts entails numerous difficulties. In the case of statutory definitions of legal terms, the challenge is to find the right definition of a given term. In a situation when the legislator has not constructed a definition of a concept, nor refers to such a definition contained in another normative act, an interpreting entity must seek a proper statutory definition. Another problem is the dilemma: was it the legislator's will to apply a common understanding of an undefined concept, or was it the legislator's will to take into account the statutory definition contained in another normative act - despite the absence of reference to such a regulation?

In turn, the use of operative definitions of legal terms in tax law is problematic because of the manner in which they are created. This means that entities applying tax law may have a different understanding of the same concept. However, it is difficult to create a legal regulation in this respect that would determine a manner of constructing definitions of operative legal concepts, as it would be a regulation related to an issue of interpretation of the law, which would itself be subject to an interpretation.

Another issue relates to quasi-statutory definitions of legal terms, which are a type of operative definitions of terms in tax law. Some entities, important in view of their political position and competences, while creating operative definitions of tax law concepts, construct ad hoc definitions that must be respected under the law by other entities applying tax law. Therefore, these definitions, albeit being operative definitions, are

Administrative Court, and therefore is also bound by the interpretation of legal terms expressed in resolutions. 
quasi-statutory by virtue of their binding force and their inclusion in the process of applying tax law.

\section{Bibliography:}

Babiarz S., Właściwość Naczelnego Sqqu Administracyjnego [in:] S. Babiarz (ed.), Postępowanie sqdowoadministracyjne $w$ praktyce, LEX a Wolters Kluwer business, Warszawa 2015.

Bielska-Brodziak A., Interpretacja tekstu prawnego na podstawie orzecznictwa podatkowego, Oficyna a Wolters Kluwer business, Warszawa 2009.

Borszowski P., Definiowanie pojęć w prawie podatkowym jako ograniczenie obszaru nieostrości, „Wrocławsko-Lwowskie Zeszyty Prawnicze”, 2017, No 8, pp. 189-198.

Borszowski P., Pomiędzy elastycznościq przepisów prawa podatkowego a definicjami legalnymi [in:] W. Miemiec (ed.), Księga jubileuszowa Profesor Krystyny Sawickiej. Gromadzenie i wydatkowanie środków publicznych. Zagadnienia finansowoprawne, Oficyna Wydawnicza „Unimex”, Wrocław 2017.

Borszowski P., Wprowadzanie definicji legalnych w prawie podatkowym - zagadnienia wyjściowe, „Wrocławsko-Lwowskie Zeszyty Prawnicze”, 2016, No 7, pp. 219-229.

Brzeziński B., Uwagi o znaczeniu definicji w prawie podatkowym [in:] R. Mastalski (ed.), Księga jubileuszowa Profesora Marka Mazurkiewicza. Studia z dziedziny prawa finansowego, prawa konstytucyjnego i ochrony środowiska, Oficyna Wydawnicza „Unimex”, Wrocław 2001.

Brzeziński B., Wstęp do nauki prawa podatkowego, TNOiK, Toruń 2003.

Brzeziński B., Wykładnia prawa podatkowego, ODiDK, Toruń 2013.

Brzeziński B., Zasady ogólne prawa podatkowego (próba inwentaryzacji), „Kwartalnik Prawno-Finansowy” 2018, No 1, pp. 23-46.

Filipczyk H., Glosa do wyroku NSA z dnia 25 stycznia 2012 r., II FSK 1445/10, „Glosa. Prawo gospodarcze w orzeczeniach i komentarzach” 2012, No 4, pp. 113-119.

Gromski W., Stanowione prawo [in:] A. Bator (ed.), Wprowadzenie do nauk prawnych. Leksykon tematyczny, LexisNexis Polska, Warszawa 2010.

Halasz A, Definicje pojęć prawnych w ustawodawstwie dotyczq̨cym podatków obrotowych, E-Wydawnictwo. Prawnicza i Ekonomiczna Biblioteka Cyfrowa. WPAiE UWr, Wrocław 2019. 
Halasz A., Stosowanie definicji stanowionych pojęć prawnych a zasada pewności w prawie podatkowym, [in:] A. Kaźmierczyk, A. Franczak (ed.), Zasada pewności w prawie podatkowym, Wolters Kluwer, Warszawa 2018.

Kostecki A., Elementy konstrukcji instytucji podatku [in:] M. Weralski (ed.), System instytucji prawno-finansowych PRL, t. III, Zakład Narodowy im. Ossolińskich - Wydawnictwo, Wrocław 1985.

Malinowski A., Redagowanie tekstu prawnego. Wybrane wskazania logicznojęzykowe, Wydawnictwo Prawnicze „LexisNexis”, Warszawa 2006.

Radzikowski K., Glosa do wyroku WSA z dnia 4 września 2008 r., I SA/Ol 165/08, „Finanse Komunalne” 2010, No 12, pp. 49-58.

Wróblewski J., Rozumienie prawa i jego wykładnia, Zakład Narodowy im. Ossolińskich, Wrocław 1990.

Wróblewski J., Sqqdowe stosowanie prawa, Państwowe Wydawnictwo Naukowe, Warszawa 1972.

Wróblewski J., Zasady tworzenia prawa, Państwowe Wydawnictwo Naukowe, Warszawa 1989. 